\title{
Use of E-consumer Services by Adult and Community Education Learners in Nairobi County, Kenya
}

\author{
Anastasia Nyawira Gakuru ${ }^{1, *}$, Joseph Mwinzi ${ }^{1}$, Joseph Nungu ${ }^{1} \&$ Samson Gunga $^{1}$ \\ ${ }^{1}$ University of Nairobi, Nairobi, Kenya \\ *Corresponding author: University of Nairobi, Nairobi, Kenya. Tel: 254-072-184-2247. E-mail: \\ agakuru@uonbi.ac.ke
}

Received: August 14, 2021 Accepted: September 9, 2021 Published: November 5, 2021

doi:10.5296/ije.v13i4.18940 URL: https://doi.org/10.5296/ije.v13i4.18940

\begin{abstract}
Technology is advancing at a fast pace and several services are being digitized as the internet and smart/digital gadgets permeate the market. Many services are now being transferred to online platforms and this study purposed to examine the adult and community education learner's use of e-consumer services in Nairobi County Kenya. The study adopted a mixedmethod research design where adult education and community instructors $(n=108)$ and adult learners $(n=375)$ were sampled together with café owners/staff. Interviews and questionnaires were used to collect data and thematic and descriptive analysis was used. The findings revealed that adult learners use e-consumer services to some extent. The study concluded that the use of e-commerce among adult learners is not high and recommends that the learners should be educated on the different types of services offered through e-commerce and how to access them.
\end{abstract}

Keywords: E-consumer, ICT, Adult literacy, digitalization, mobile money 


\section{Background to the Study}

E-consumer services entail the use of technological advancement through the internet. It requires the use of modern technologies like the World-Wide-Web, (WWW), and Information Communication and Technology (ICT) to electronically offer non-governmental and government amenities to businesses, citizens, civil servants, and private investor organizations (United Nation, 2010). UNESCO (2014), states that the adaption of these technologies in governmental systems and non-government (NGOs) sectors offers improved and better service and information delivery to citizens. These digitized services offer efficient and effective access to information increasing interactions with business and industry, citizen empowerment, and public-sector management. These benefits of E-Consumer services also offer increased transparency, revenue growth, reduced corruption, greater convenience, and cost reductions (Mazlan, Redzuan, \& Bakar, 2014).

In Paris, the E-consumer approach embraced in the early 2000s stressed the transformation of end-user retailed services to digital-based setups from manual recordings to the use of ICT (Cohen, Prayag \& Moital, 2014). These E-consumer services are being integrated for use in executing and accessing state-owned service provision in departmental and institutional requirements offering end-user or consumer services to individualized custom-made services for citizens, corporates, and businesses (Seidel, \& Blanquart, 2020). The digitalization of enduser services has widened the need for ICT knowledge especially for the elder members of the society which leads to better delivery of services to its citizens. These digitalized consumer/end-user services include but are not limited to; domesticated taxing systems, human immigration information systems, legal information systems, educational oriented systems, integrated financial executive systems among others (Deloitte, 2013; Khan, 2016).

In many African countries, providers of adult education include civic and international organizations, trade unions, community-based and regional organizations, the family, as well as governments, and non-governmental organizations (Mohammed, 2013). ICT has both the potential to facilitate development and create a digital divide as well. This has created divergent views among researchers, policymakers, and development partners (Mulama 2011; Kabugumila, Lushakuzi, \& Mtui, 2016). This is because many African countries are still struggling to provide basic needs to their citizens such as affordable food and clean water, affordable housing, and proper and affordable medical care (Islam, \& Eva, 2019). Provision of ICT technologies is seen as a secondary need. On the contrary other researchers e.g. Lu, Hou, and Huand (2010); Motschilnig, (2014), are of the view that ICT has a key to play in contributing to improving the situation of communities that are already disadvantaged in so many other ways to kick out poverty and break the gender divide as well (Seidel, \& Blanquart, 2020).

Khan and Uwemi (2018) have also noted that a major interest among policy-makers, researchers, and others is the effective use of communications technologies for education and creating wealth and opportunities within the many remote regions in Africa (Nantembelele, \& Gopal, 2018). This is because ICT is incorporated in the teaching and learning processes of the adult learners it can be a crucial tool for capacity building enabling the adult learners to survive 
in today's changing social and economic landscapes (Putera \& Mokhtar, 2014).

The use of ICT in Kenya is guided by several policies and other Government documents. Such policies include the National ICT policy (2006), Sessional Paper no.1 (2005), The National ICT strategy for education and training (2006), Kenya Vision 2030 Development Programme (2007), Ministry of education strategic plan (2006-2011) among others (Makini, Mose, Kamau, Mulinge, Salasya, Akuku, \& Makelo, 2020). Looking into the GoK report (2006), the principal objective of the National ICT Policy is to facilitate sustainable economic growth and development, and poverty eradication through productive and effective technologies. It also seeks to stimulate investment in the ICT sector while at the same time encouraging the spirit of innovation through research and development. These show that the Kenyan government is committed to providing ICT adoption, education, and use in most of the government sectors and institutions (Makini, et al., 2020). E-consumer services have also been introduced in most government services for example introduction of I-tax, which is a tax-filing system done online to substitute the previous monotonous paper-based particle systems (Janssen, 2012; Seidel, \& Blanquart, 2020). Additional facilities currently offered on digital platforms include business permits applications procedures, applications and renewals of driving licenses, business registrations, and application for passports, electronic money transfers popularly known as MPesa and M-Akiba amid others (Njoroge, 2021).

According to Mbugua (2009) and NACEP report (2010), there has been a slow integration of ICT in the teaching of adult learners. The sluggish uptake of digital literacy in almost every consumer service attributes to challenging factors which include high levels of poverty, inadequate equipment funding, and inaccessible information hindering effective access to ICT facilities, frequent power disruption, and limited rural electrification ((Mensah, 2019; Omondi, 2020). To implement the ICT fully requires integration with adult education, which advocates for lifelong learning for adult learners (Njoroge, 2021).

Additionally, different government and parastatal agencies are currently insisting on digitizing all their operations. For instance, Kenya Revenue Authority (KRA), requires the online filing of personal and business taxes returns (Kimathi, Mukulu, \& Odhiambo, 2019). However, this evolution of the digital generation and increased digitization has impacted negatively on the adult and community learners. This is because adult learners in adult and community education centers are still being taught basic literacy, which is focusing on reading writing, and simple arithmetic contrary to the global digital world practices (Omondi, 2020). That requires one to have at least basic digital literacy. The adults then need to depend so much on aided assistance in accessing digitalized E-consumer services for example annual tax returns and driving licenses renewal. Overdependence on aided assistance in the utilization of E-consumer services jeopardizes the cost implications and intrusion to the privacy of sensitive individuals' information due to overreliance on strangers to execute their e-consumer service needs (Mensah, 2019).

Ultimately, in Kenya, as in most developing countries, adult and community education is still in the infancy stage, revolving around the basic stage where learners are still at the basic literacy level (Kimathi, Mukulu, \& Odhiambo, 2019). In Kenya, the foregoing discussion shows the 
efforts from both the government and private sectors that have adopted numerous E-Consumer services in individualized service provision systems such as online tax filing (i-Tax), driving licenses application and renewal, passports application/replacement/renewal, and business registrations among others (Gitari, 2020). In the business facade, Kenya dominates as the world leader in mobile-phone money transfer technology, like M-Akiba and M-Pesa. Kenyans, both old and young adults, literate and illiterate, are now increasingly faced with the necessity to use electronic services for their e-consumer needs (Njoroge, 2021). A pertinent question, therefore, questions, to what extent do adult and community education programs offered in Kenya prepare learners to use the available E-Consumer services. It is in this regard that the study seeks to evaluate the e-consumer services used by adult and community education learners in Nairobi County, Kenya.

\section{Literature Review}

Virtually everyone needs a high level of literacy in both print and digital media to negotiate most aspects of 21 st-century life-succeeding in a competitive job market, supporting a family, navigating health information, and participating in civic activities (Rasouli, Ahqr, \& Asadzadeh, 2020). Yet, according to a recent survey estimate, more than 90 million adults in the United States lack the literacy skills needed for fully productive and secure lives. Although using technologies will likely add to the initial cost of literacy programs, the degree of differentiated and sustained support they can provide to adult literacy learners is great enough that investments in technology may be the most cost-effective solution (Xu, Banerjee, Ramirez, Zhu, \& Wijekumar, 2019). Thus, it is worth developing and testing the most promising new approaches so that their costs and benefits are better understood. Consumer literacy includes such knowledge as understanding consumer rights and marketing practices, having the interpersonal skills to manage service encounters and make complaints, and asserting one's voice, and achieving agency in the marketplace. This broader idea of consumer competency does not dwell within the consumer alone but is socially enacted and evaluated. A social practice approach to literacy conceptualizes adults to be "acting in relation to a situation, taking into account other people, social and cultural norms, their own experience, and, of course, the technical knowledge they need to encode or decode" text ((Rasouli, Ahqr, \& Asadzadeh, 2020). The proliferation of various forms of literacy - computer literacy, health care literacy, financial literacy, and so on - points to the contextual factors implicated in the importance of the broad practice of consumer literacy.

Many studies of the effectiveness of technologies in education have shown minimal and sometimes null results. This is not surprising as technology does not of itself produce learning; it simply amplifies and extends instructional strategies (Müller, \& Wulf, 2020). Too often, studies of technology effectiveness have paid inadequate attention to the content of the instruction and assumed that any technological strategy to amplify it would be effective. Neither do the studies attend sufficiently to the engineering and training required to implement the technologies effectively. If well engineered and supported, the technologies described in this section could be used to amplify and extend effective instructional approaches. 
The global population is approximately 7 billion with more than half living in the Asia-pacific region. The report further indicated that more people have access to mobile phones than have flush toilets and electricity. This implies that people are embracing new and modern technology very fast. There is also an increasing expectation from citizens for easier access to more public information and government services from anywhere, anytime through different channels. This makes the public sector to be under pressure to transform itself to respond to changes and radically explore new ways to meet demands. (Walji, Deacon, Small \& Czerniewicz, 2016)

In 2012, the Netherlands and the Republic of Korea topped the list of performances in eparticipation. The countries provided an online calendar of participatory events by the government, online procurement announcements, and an online citizen's right to government information. (OECD 2008). This led to better delivery of service and decision-making among its citizens. According to United Nations Survey, in 2014 Almost $40 \%$ of the world's population was online by the end of 2013; but in Africa, only $16 \%$ of people are using the internet. Mobile phone subscriptions exceeded 6 billion in October 2012 (Maijo, 2020).

Many countries are increasingly embracing digital channels, including counter services, telephone service, web portal, e-mail, SMS, mobile portal, mobile app, social media, public kiosks, and intermediaries through public private partnerships (Sebastian, 2011; Njoroge, 2021). The local Government of Amman, the capital of Jordan, has launched an SMS service portal that aims at increasing the channels of communication between citizens and governments (Yousef, Chatti, Schroeder, \& Wosnitza, 2015).

In Singapore, the government has launched an SMS text service for members of the deaf, hardof-hearing, and speech-impaired community to reach emergency services (OECD, 2013). Cell phone payment is an increasing trend particularly in developing countries (Xiao, Li, Qiao, \& Liang, 2020). M-Pesa is one striking example of a mobile money service in Africa that boosts employment and fights poverty. It started in Kenya and it allows users to make deposits and withdrawals, transfer funds, and pay bills, offering financial services in countries where banks and road infrastructure are still developing and yet meeting financial rules and regulations (United Nations Survey, 2014; Omondi, 2020). The rise of mobile payments is expected with much of the continent's population living in rural areas, with little access to ICT infrastructure (Wagunya, 2018). M-Pesa has expanded to include mobile airtime top-up, salary payments, interest-earning savings account and international money transfer (Njoroge, 2021). This application is mostly used by adults aged 18 years and above since one is required to have a national identification card to make any transaction.

Public kiosks are public-access facilities providing free access to online services especially in marginalized or remote areas where ICTs are not prevalent. They are either funded by governments or supported through a public-private partnership. such technologies normally serve several concurrent functions including, among others, enabling communities and citizens to access new knowledge and information (Wagunya, 2018). Such information and knowledge can be incorporated into local knowledge and context by the provision of information like planting techniques and disease prevention, better-eating habits, and other government information and services. Public kiosks also provide the means for intermediaries to assist 
citizens in accessing public information and services. (UN E-Government survey 2012)

The government of Kenya is putting a lot of emphasis on the use of ICT facilities in the government sector (Wairiuko, Nyonje, \& Omulo, 2018). It is worth noting that, Kenya has led the world in mobile money/ electronic cash transfer the government has also taken the initiative to digitalize most of its services to the people. However, there is a minimal indication that adult learners are being taught how to use the new technology (Wagunya, 2018). This study sought to find out if the adult learners are being taught how to use these services and if the adult learners are benefiting in any way from the services being provided by the government.

\section{Methodology}

This study adopted a mixed-method design. The mixed-method is a combination of quantitative and qualitative research techniques. (Teddie \& Tashakkori, 2012). Mertens, (2010) further asserts that mixed-method design is one in which both quantitative and qualitative methods are used to answer research questions in a single study. Creswell, (2015) emphasizes that the strength of mixed methods research lies in its ability to bring the two approaches together in a complementary way to address the inherent weaknesses of each. Thus, based on Creswell's (2012) further argument a mixed-method research design entails a procedure starting from collecting, analyzing to mixing both qualitative and quantitative research methods in a single study to enhance in-depth understanding of particular research concerns. This method of research design increases the rationalization of the sought problem to increase the researcher's insight on known phenomena about certain conditions of a particular problem. Mixed methods design's principles on prioritizing and sequential collection and analysis of data on social subjects enhance interaction between qualitative and quantitative strands.

The design was appropriate for this study because the researcher collected qualitative and quantitative data concurrently year the analysis of the two sets was done separately. The two sets of data were mixed by merging results during interpretation to compare and relate the results. The use of mixed methods was used for reviewing e-consumer services on adult and community education is a complex and multifaceted process that entails in-depth qualitative and quantitative data. On the one hand, it will be important to highlight and interrogate the metrics of adult and community education, thus quantitative data. Equally important, on the other hand, will be qualitative data entailing the voices (opinions, and experiences) of the different stakeholders. Hence, the mixed methods design was selected for this study to generate a greater understanding of the impact of e-consumer services on adult and community education in Nairobi County, Kenya.

The quantitative data was given a general overview of the access and utilization of e-services as well as establishing the relationship between utilization of e-service and provision of adult education in Kenya. However, the quantitative data alone may not enable deeper explanations as to why a phenomenon occurs. This dimension necessitates the use of qualitative data. Hence, the qualitative approach was employed to get data that capture the different dimensions of respondents' experiences, personal perspectives and meanings, values, norms, and beliefs 
regarding the impact of e-consumer services on adult and community education in Nairobi County, Kenya.

The target population of the study comprised all Adult education officers in the Nairobi subcounty, adult learners, and tutors in all adult learning institutions in Nairobi County. According to a report in the Office of Adult Education in Nairobi County 2018, there is one adult education officer in each sub-county, 13,531 adult learners, 223 tutors in 220 educational centers. The other target population included management officers in e-consumer service providers that is Huduma center as well as cyber café providers designated by Huduma Center to offer econsumer services are to be sought. Nairobi County was chosen because it is the headquarters of the country and therefore the hub of e-consumer services.

Table 1. Distribution of Target Population

\begin{tabular}{rllrlr}
\hline NO. & Sub country & No. of centers & No. of tutors & \multicolumn{2}{c}{ Total No. of Adult learners } \\
\hline 1 & Makadara & 8 & 15 & 348 \\
2 & Dagorreti & 18 & 19 & 2194 \\
3 & Westlands & 18 & 32 & 433 \\
4 & Kasarani & 35 & 10 & 3011 \\
5 & Mathare & 19 & 18 & 368 \\
6 & Njiru & 20 & 15 & 967 \\
7 & Kamukunji & 28 & 26 & 2253 \\
8 & Langata & 17 & 24 & 741 \\
9 & Kibra & 15 & 29 & 675 \\
10 & Embakasi & 23 & 223 & 611 \\
11 & Starehe & 19 & 220 & 1960 \\
& TOTAL & & 13561 \\
\hline
\end{tabular}

Source: Nairobi County Adult and Community Education Office 2018

According to Lodico, Spaulding, and Voegtle (2010) sampling entails a careful selection of a sub-group that is representative of the whole population with relevant characteristics. Garson (2013), further adds that sampling saves time and money when compared to complete coverage of the population, which would take more time and require more resources in terms of finances. Garson (2013) also observes that dealing with a sample may permit the researcher to focus on the finer details and increase the level of accuracy and precision than when dealing with a large amount of data from the entire population.

To determine the study sample size of adult learners the researcher used Slovin's formula (Matula, Kyalo, Mulwa \& Gichuhi, 2018):

$$
\mathrm{n}=\frac{N}{1+N e^{2}}
$$


Where: $\mathrm{n}=$ sample size

$\mathrm{N}=$ size of population

$\mathrm{e}=$ margin of error $(0.05)$

Therefore, by substitution, this was follows

$\mathrm{n}=\left[\frac{13531}{1+\left(13531 * 0.05^{2}\right)}\right]=389$ adult education Learners.

To get the sample size for the tutors, the study was guided by Neuman (2013) who recommended $50 \%$ of the target population. The tutors were drawn from $50 \%$ randomly selected adult education centers in Nairobi Sub-county. This is as distributed in Table 2.

Table 2. Sampling Matrix for Adult Learners, Tutors, and Centers

\begin{tabular}{|c|c|c|c|c|c|c|c|}
\hline No. & $\begin{array}{l}\text { Sub } \\
\text { County }\end{array}$ & $\begin{array}{l}\text { Total } \\
\text { No. of } \\
\text { centers }\end{array}$ & $\begin{array}{l}\text { Sample for } \\
\text { centers } \\
\text { using } \\
\text { formulae } \\
50 / 100 * \mathrm{~N}\end{array}$ & $\begin{array}{l}\text { Total } \\
\text { No. of } \\
\text { tutors }\end{array}$ & $\begin{array}{l}\text { Sample for } \\
\text { tutors using } \\
\text { formulae } \\
50 / 100 * \mathrm{~N}\end{array}$ & $\begin{array}{l}\text { Adult } \\
\text { learners } \\
\text { total }\end{array}$ & $\begin{array}{l}\text { Adult } \\
\text { learners(samp } \\
\text { le using } \\
\text { Slovings } \\
\text { formulae }\end{array}$ \\
\hline 1 & Makadara & 8 & 4 & 15 & 8 & 348 & 10 \\
\hline 2 & Dagorreti & 18 & 9 & 19 & 10 & 2194 & 63 \\
\hline 3 & Westlands & 18 & 9 & 18 & 9 & 433 & 12 \\
\hline 4 & Kasarani & 35 & 17.5 & 32 & 16 & 3011 & 86 \\
\hline 5 & Mathare & 19 & 9.5 & 10 & 5 & 368 & 11 \\
\hline 6 & Njiru & 20 & 10 & 18 & 9 & 967 & 28 \\
\hline 7 & Kamukunji & 28 & 14 & 27 & 14 & 2253 & 65 \\
\hline 8 & Langata & 17 & 8.5 & 15 & 8 & 741 & 21 \\
\hline 9 & Kibra & 15 & 7.5 & 26 & 13 & 675 & 19 \\
\hline 10 & Embakasi & 23 & 11.5 & 24 & 12 & 611 & 18 \\
\hline \multirow[t]{2}{*}{11} & Starehe & 19 & 9.5 & 29 & 15 & 1960 & 56 \\
\hline & TOTAL & 220 & 110 & 223 & 112 & 13561 & 389 \\
\hline
\end{tabular}

Source: Researcher

To get the adult education learners, tutors, and adult education centers who participated in the study, simple random sampling was used. In this case, the list of all students from each center was be made and a certain number will be picked using the replacement method. This enabled all the learners, tutors, and centers to have an equal probability of being picked. However, to get the respondents from Huduma centers, and Cyber cafée offering e-consumer services, purposive sampling was used. This will involve picking the senior manager from each of the institutions/organizations/enterprises. This is because the senior managers are more conversant 
with the running of the organization.

The study used questionnaires and interview schedules to collect data from the selected respondents as per the objectives of the study. A questionnaire was used to gather data from tutors and adult education students. According to Patton (2015), self-administered questionnaires were appropriate for survey studies because they are easy and inexpensive to administer. They also maintained the confidentiality of research participants. Questionnaires for adult learners and instructors/facilitators included both open-ended and close-ended questions. The interview schedule was used to gather information from officers in the County education offices, managers from Huduma Centres, and selected cyber café persons.

A pilot study was being carried out before the implementation of the actual study. Piloting was important since the researcher was able to confirm whether the instruments of the research were clear to the respondents and whether they would yield relevant and adequate data for the study. According to Orodho (2005), piloting is also important in that it helps to assess and identify any problems respondents would encounter in completing the questionnaires that may not have been foreseen when constructing the questionnaires. Piloting was conducted in the sub-counties that were not be involved in the main study.

Veal and Darcy (2012) argue that validity is the extent to which information collected by the researcher truly reflects the phenomenon being studied. To enhance content validity, appropriate and adequate items relevant to research objectives will be contained in the questionnaires. Validation was done by use of expert judgment where my supervisors who are experts in the area will check whether the research instruments are valid and in line with the study objectives.

Reliability of the instruments refers to the consistency of scores or answers from one administration of an instrument to another, and one set of items to another (Patton, 2015). The questionnaire was pre-tested using the split-half method with all the questions except those that seek respondents' recommendations. It involved scoring two halves (odd versus even items) of a test separately for each respondent and then calculating a correlation coefficient for the two sets of scores using the Pearson product-moment correlation formula.

The researcher engaged research assistants in data collection. The research assistants were trained to familiarize themselves with the questionnaires. They administer the questionnaires to the respondents and then pick them later after they have been filled up. The researcher also interviewed the cyber café manager by going to the cybers and filling up the interview schedule, Huduma center managers and county education officers all were also filled up an interview schedule as guided by the interviewer.

According to Yin (2015), data analysis is the process of bringing order and meaning to raw data collected. After the questionnaires have been collected the researcher then checked for completeness, the accuracy of the information, and uniformity. Descriptive statistics such as frequency distribution and percentages were used to analyze the data collected. Tables were used to present responses for each item that was used. Qualitative data from open-ended questionnaire items and responses to interview questions were organized and analyzed 


\section{Ml Macrothink}

thematically. Such data was presented qualitatively, using in-depth descriptions and direct quotations.

This study adhered to all research ethical considerations, namely, official research protocols, participant informed consent, confidentiality, anonymity, and protection of data. Formal permission to conduct the study was sought from the National Commission for Science, Technology, and Innovation. Thereafter, the researcher wrote an introductory letter to research participants detailing the purpose of the research. Participants were then briefed on data collection, their rights as participants, including the right to participate or to withdraw from the research. The participants were assured of the confidentiality of their responses and the anonymity of their identifications. This was achieved by ensuring research participants' names, personal numbers, or any other forms of identification are not indicated on the questionnaire and the final report. The interviewees were identified as interviewees 1, 2, or 3 when quoting them verbatim in the report to ensure confidentiality. All returned questionnaires as well as transcripts of interview responses will be stored securely in the researcher's office.

\section{Analysis}

This section presents the data analyzed descriptively and inferentially.

\subsection{Demographic Analysis}

Table 3. Demographic Characteristics-Adult Instructors

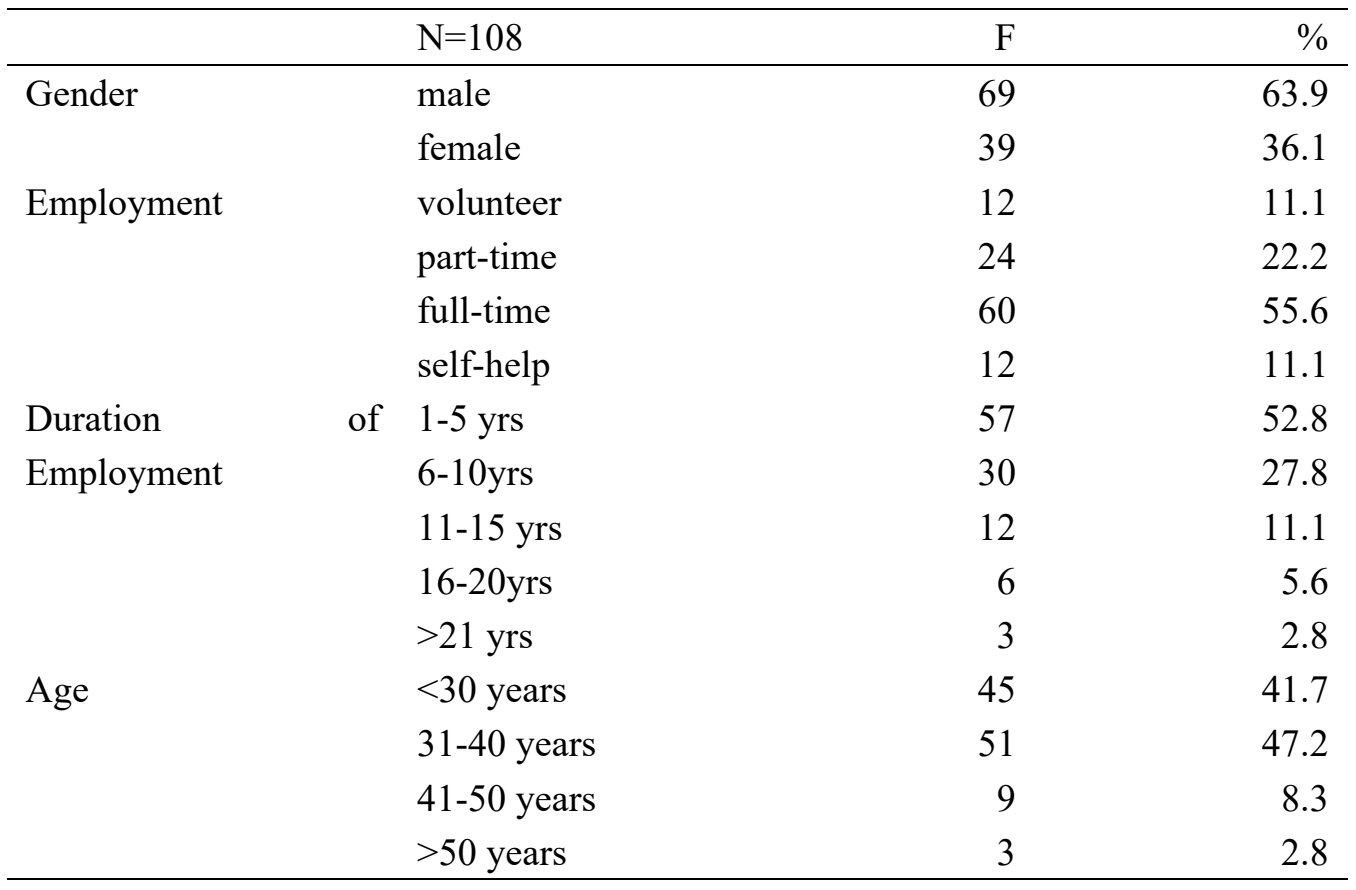




\section{Macrothink

Table 3 shows the demographic characteristics of the adult instructors where the majority $69(63.9 \%)$ of the instructors were male while the females were the minority at 39(36.1\%). In regards to employment, most of the respondents $60(55.6 \%)$ were employed full time while $24(22.2 \%)$ were part-time employees, $12(11.1 \%)$ were volunteers and self-help respectively. Most of the respondents 57(52.3\%) had been employed for between 1 to 5 years, 30(27.8\%) had been employed for between six and ten years and 12(11.1\%) had been employed for between 11 and 15 years while only 6(5.6\%) and 3(2.8\%) had been in employment for between 16-20 years and more than 21 years respectively. In regards to age, most of the respondents were below forty years $96(88.9 \%)$.

Table 4. Demographic Characteristics-Adult Learners

\begin{tabular}{|c|c|c|c|}
\hline & $\mathrm{N}=375$ & $\mathrm{~F}$ & $\%$ \\
\hline \multirow[t]{2}{*}{ Gender } & Female & 240 & 64.0 \\
\hline & Male & 135 & 36.0 \\
\hline \multirow[t]{5}{*}{ Age } & Below 18 years & 24 & 6.4 \\
\hline & $18-29$ years & 213 & 56.8 \\
\hline & $30-39$ years & 90 & 24.0 \\
\hline & 40 - 49 years & 24 & 6.4 \\
\hline & 50 - 59 years & 24 & 6.4 \\
\hline \multirow{3}{*}{$\begin{array}{l}\text { Duration in the } \\
\text { institution }\end{array}$} & Below 1 year & 54 & 14.4 \\
\hline & 1 - 2 years & 207 & 55.2 \\
\hline & 3 years and above & 114 & 30.4 \\
\hline \multirow{4}{*}{$\begin{array}{l}\text { The time they attend } \\
\text { school }\end{array}$} & $9 \mathrm{am}$ to $3.30 \mathrm{pm}$ & 150 & 40.0 \\
\hline & 8 am to $11 \mathrm{am}$ & 123 & 32.8 \\
\hline & $2 \mathrm{pm}$ to $5 \mathrm{pm}$ & 72 & 19.2 \\
\hline & 11 am to $2 \mathrm{pm}$ & 30 & 8.0 \\
\hline Adult learners & Beginner & 45 & 12.0 \\
\hline \multirow[t]{2}{*}{ learning level } & Intermediate & 120 & 32.0 \\
\hline & Advance & 210 & 56.0 \\
\hline \multirow[t]{3}{*}{ Employment Status } & Business & 108 & 28.8 \\
\hline & Employed & 63 & 16.8 \\
\hline & Not working & 204 & 54.4 \\
\hline Type of Adult & Self- sponsored & 204 & 54.4 \\
\hline \multirow[t]{2}{*}{ Learners } & Sponsored & 150 & 40.0 \\
\hline & Partial Sponsored & 21 & 5.6 \\
\hline \multirow[t]{4}{*}{ Sponsorship body } & Government & 78 & 20.8 \\
\hline & NGO & 63 & 16.8 \\
\hline & Not applicable & 165 & 44.0 \\
\hline & Relatives & 69 & 18.4 \\
\hline
\end{tabular}




\section{Macrothink}

The majority of adult learners $210(56 \%)$ were in the advanced stage while $120(32 \%)$ were in the intermediate stage with only $45(12 \%)$ being beginners. Most of the learners 204(54.4\%) were not working while $108(28.8 \%)$ were in business and only $63(16.8 \%)$ being employed. Most of the students 204(40\%) were self-sponsored while 150(40\%) were sponsored and only $21\left(5.6^{\wedge}\right)$ were partially sponsored. Lastly, the table shows that most of the students $165(44 \%)$ were not using sponsorship while the government-sponsored 78(20.8\%), NGOs sponsored $63(16.8 \%)$, and relatives sponsored $69(18.4 \%)$ of the adult learners. Table 2 shows that the majority of adult learners $240(64.0 \%)$ were females while the males were $135(36.0 \%)$. In regards to the duration in the adult learning institution, most of the learners 207(55.2\%) and $114(30.4 \%)$ had been in the institution for between 1-2 years and more than three years respectively. Further, the majority 213(56.8\%) were between ages 18-29. The adult learners also attended school between nine am to three-thirty pm 150(40\%) and eight am to eleven am $123(32.8 \%)$.

\subsection{Use and Access}

The researcher asked the adult learners whether they use e-commerce services. Their responses are provided in table 5 .

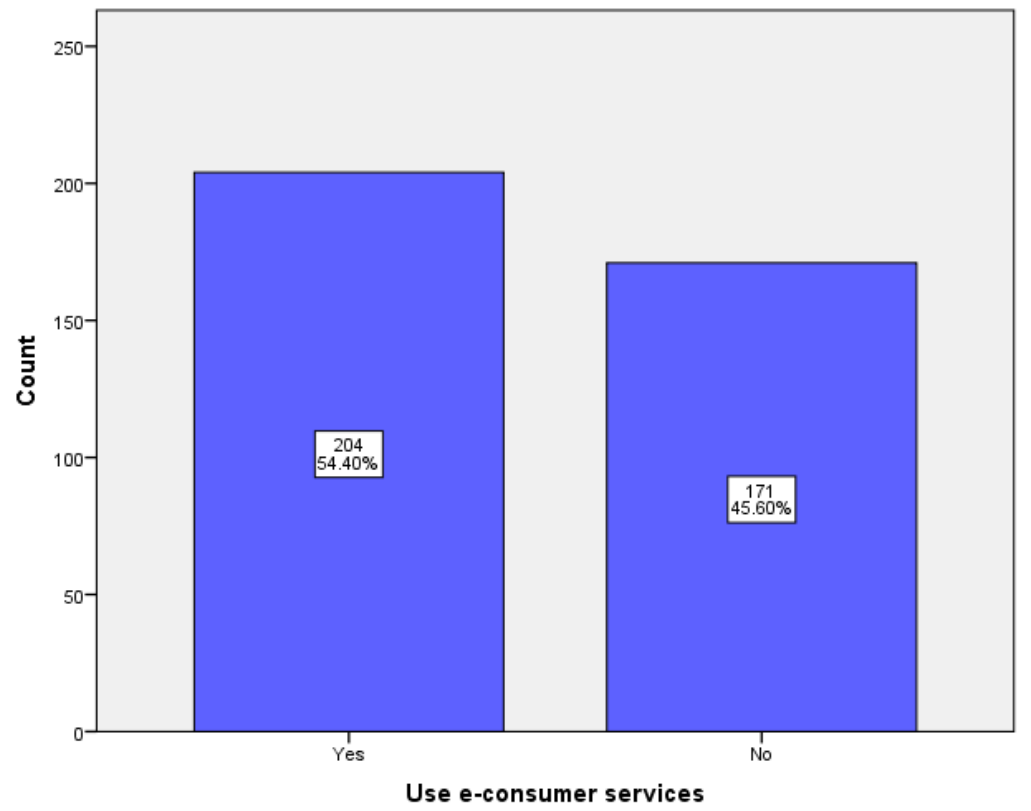

Figure 1. Use of E-consumer Services

Figure 1 shows that the majority of respondents 204(54.4\%) indicated that they use ecommerce services while 171(45.6\%) indicated they never use e-consumer services. 


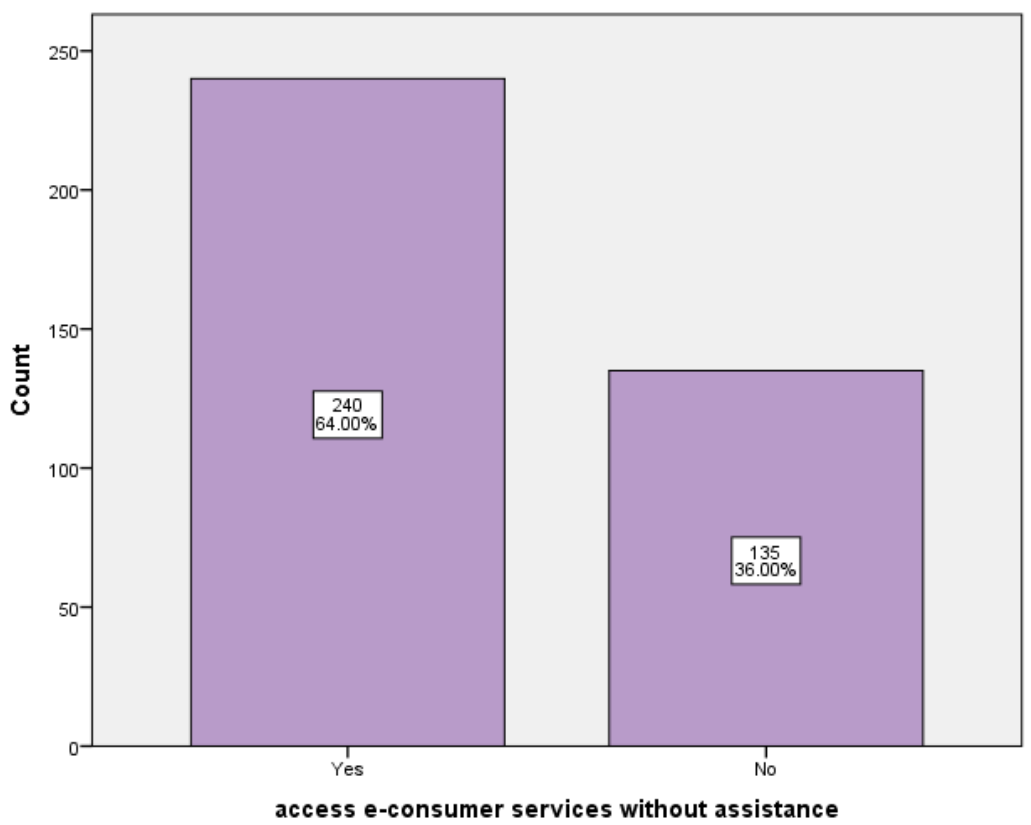

Figure 2. Access e-consumer Services

Figure 2 shows that the majority of respondents 240(64\%) access e-consumer services without assistance while 135(36\%) need assistance.

Access
point
$\square$ Smart phone
$\square$ Cybercafes
$\square$ Not applicable

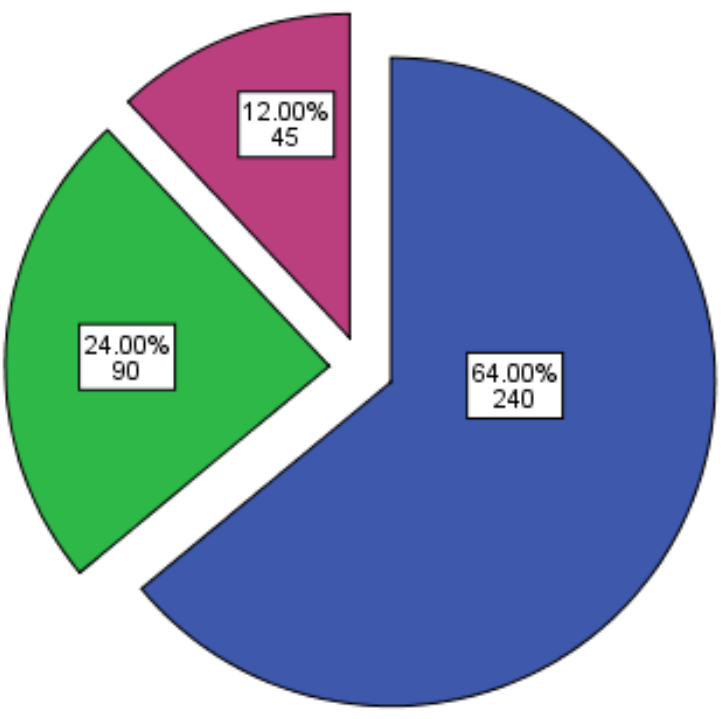

Figure 3. Access Point 
The study found that the majority of adult students access e-consumer services using smartphones 240(64\%) while 90(24\%) access e-consumer services through cybercafés while $45(12 \%)$ indicated that they were not applicable as presented in figure 3 . The interviews with the cyber café owners and staff showed that some of the adults knew how to access the services, but the majority were not familiar with the use of digital services.

\subsection{E-commerce Use}

The respondents were asked to indicate the extent to which they agreed with the statements in table $41=$ Not at all, 2= Very Little Extent, 3= Little Extent 4 Some Extent, 5= Great Extent, $6=$ Very Great Extent.

Table 5. Use of E-consumer Services

\begin{tabular}{|c|c|c|c|c|c|c|c|c|c|c|c|c|}
\hline \multirow[t]{2}{*}{ Statement } & & \multicolumn{5}{|c|}{ Adult learners $\mathrm{N}=375$} & \multicolumn{6}{|c|}{ Adult Instructors $\mathrm{N}=108$} \\
\hline & & 1 & 3 & 4 & 5 & 6 & 1 & 2 & 3 & 4 & 5 & 6 \\
\hline \multirow[t]{2}{*}{ National ID } & $\mathrm{F}$ & 81 & 75 & 81 & 75 & 63 & 30 & 24 & 9 & 30 & 6 & 9 \\
\hline & $\%$ & 21.6 & 20 & 21.6 & 20 & 16.8 & 27.8 & 22.2 & 8.3 & 27.8 & 5.6 & 8.3 \\
\hline \multirow[t]{2}{*}{ Driving License } & $\mathrm{F}$ & 81 & 69 & 105 & 72 & 48 & 24 & 36 & 9 & 27 & 6 & 6 \\
\hline & $\%$ & 21.6 & 18.4 & 28 & 19.2 & 12.8 & 22.2 & 33.3 & 8.3 & 25 & 5.6 & 5.6 \\
\hline Revenue & $\mathrm{F}$ & 84 & 93 & 78 & 69 & 51 & 30 & 21 & 12 & 30 & 6 & 9 \\
\hline Form & $\%$ & 22.4 & 24.8 & 20.8 & 18.4 & 13.6 & 27.8 & 19.4 & 11.1 & 27.8 & 5.6 & 8.3 \\
\hline \multirow[t]{2}{*}{ M-Pesa } & $\mathrm{F}$ & 72 & 87 & 81 & 48 & 87 & 18 & 18 & 12 & 33 & 12 & 15 \\
\hline & $\%$ & 19.2 & 23.2 & 21.6 & 12.8 & 23.2 & 16.7 & 16.7 & 11.1 & 30.6 & 11.1 & 13.9 \\
\hline \multirow[t]{2}{*}{ Mobile Banking } & $\mathrm{F}$ & 63 & 69 & 90 & 78 & 75 & 12 & 6 & 3 & 6 & 15 & 66 \\
\hline & $\%$ & 16.8 & 18.4 & 24.0 & 20.8 & 20 & 11.1 & 5.6 & 2.8 & 5.6 & 13.9 & 61.1 \\
\hline \multirow[t]{2}{*}{ Passport } & $\mathrm{F}$ & 90 & 63 & 78 & 99 & 45 & 21 & 6 & 9 & 9 & 18 & 45 \\
\hline & $\%$ & 24 & 16.8 & 20.8 & 26.4 & 12 & 19.4 & 5.6 & 8.3 & 8.3 & 16.7 & 41.7 \\
\hline ownership & $\mathrm{F}$ & 81 & 57 & 81 & 114 & 42 & 36 & 33 & 9 & 12 & 12 & 6 \\
\hline search & $\%$ & 21.6 & 15.2 & 21.6 & 30.4 & 11.2 & 33.3 & 30.6 & 8.3 & 11.1 & 11.1 & 5.6 \\
\hline Company & $\mathrm{F}$ & 81 & 60 & 90 & 111 & 33 & 24 & 33 & 9 & 18 & 15 & 9 \\
\hline registration & $\%$ & 21.6 & 16.0 & 24.0 & 29.6 & 8.8 & 22.2 & 30.6 & 8.3 & 16.7 & 13.9 & 8.3 \\
\hline Company & $\mathrm{F}$ & 66 & 75 & 111 & 93 & 30 & 24 & 39 & 6 & 21 & 12 & 6 \\
\hline search & $\%$ & 17.6 & 20.0 & 29.6 & 24.8 & 8 & 22.2 & 36.1 & 5.6 & 19.4 & 11.1 & 5.6 \\
\hline
\end{tabular}

The table shows that the adult learners views were highly dispersed with $81(21.6 \%)$ indicating that they do not use e-consumer platforms to access National ID at all, 75(20\%) use to a little extent, $81(21.6 \%)$ use it to some extent, $75(20 \%)$ use it to a great extent and $63(16.8 \%)$ use it to a very great extent. The findings suggest that National ID is accessed over e-commerce platforms to a moderate extent by most adult learners. According to the instructors, the majority of the respondents $24(22.2 \%)$ and $39(36.1 \%)$ indicated that their learners do not use econsumer for National ID services and to a very little extent respectively. The other $6(5.6 \%)$ indicated that they use it to a little extent, 21(19.4\%) indicated their learners use it to some 
extent, $12(11.1 \%)$ use it to a great extent and 6(5.6\%) indicated that their learners use the platform to access national ID services to a great extent respectively. These digitalized consumer/end-user services include but are not limited to; domesticated taxing systems, human immigration information systems, legal information systems, educational oriented systems, integrated financial executive systems among others (Deloitte, 2013). These findings, therefore, suggest that adult earners use e-consumer services to access their driving and national IDs based on the online platforms present.

The table further shows that most of the adult learners 105(28\%) use e-consumer services for driving licenses to some extent while $81(21.6 \%)$ do not use it at all while $69(18.4) \%$ use it to a little extent. Only $72(19.2 \%)$ use it to a great extent and $48(12.8 \%)$ use it to a very great extent to access driving license services. Similar responses were solicited from the instructors where $24(22.2 \%)$ indicated that the learners use e-consumer services to access driving licenses, $39(36.1 \%)$ to a very little extent, $6(5.6 \%)$ to a little extent, $21(19.4 \%)$ to some extent, $12(11.1 \%)$ to a great extent and $6(5.6 \%)$ to a very great extent. These findings suggest that adult learners use online platforms to access their driving license which is similar to the findings by Cohen, Prayag \& and Moital, 2014) who found that E-consumer services are being integrated for use in executing and accessing state-owned service provision in departmental and institutional requirements offering end-user or consumer services to individualized custom-made services for citizens, corporates, and businesses. The digitalization of end-user services has widened the need for ICT knowledge especially for the elder members of the society which leads to better delivery of services to its citizens.

The table also shows that the majority of the adult learners $87(23.2 \%)$ use it to a little extent, $81(21.6 \%)$ use it to some extent and $72(19.2 \%)$ do not use it at all to access Kenya revenue forms. Contrary, only $69(18.4 \%)$ use it to a great extent to access Kenya revenue forms and $51(13.6 \%)$ used it to a very great extent. The instructors indicated that $30(27.8 \%)$ use it to no extent, $21(19.4 \%)$ to a very little extent, $12(11.15)$ to a little extent, $30(27.8 \%)$ to some extent, $6(5.6 \%)$ to a great extent and $9(8.3 \%)$ to a very great extent to file KRA revenues. The finding suggests that several learners use the platforms to access KRA forms. These findings are in line with Best and Khan, (2011) have also noted that a major interest among policy-makers, researchers, and others is the effective use of communications technologies for education and creating wealth and opportunities within the many remote regions in Africa. This is because ICT is incorporated in the teaching and learning processes of the adult learners it can be a crucial tool for capacity building enabling the adult learners to survive in today's changing social and economic landscapes (Putera \& Mokhtar, 2014).

Further, most of the adults $87(23.2 \%)$ and $81(21.6 \%)$ use e-commerce to access mobile banking to a little and some extent respectively. however, 63(16.8\%) indicated they do not access mobile banking while $78(20.8 \%)$ and $75(20 \%)$ use it to a great extent and to a very great extent respectively to access mobile banking. The findings also indicate that the instructors generally indicated that $15(13.9 \%)$ use mobile banking to no extent, $6(5.6 \%)$ to a very little extent, $3(2.8 \%)$ to a little extent, $6(5.4 \%)$ to some extent, $15(13.9 \%)$ to a great extent and $66(61.1 \%)$ indicated that the adult learners use mobile banking to a very great extent. These findings are almost similar to those of the adult learners showing that mobile banking is used by adult 
learners to a great extent. These findings suggest that the use of mobile banking services by adult services is improving. According to the United Nations (2014) Cell phone payment is an increasing trend, particularly in developing countries. M-Pesa is one striking example of a mobile money service in Africa that boosts employment and fights poverty. It started in Kenya and it allows users to make deposits and withdrawals, transfer funds, and pay bills, offering financial services in countries where banks and road infrastructure are still developing and yet meeting financial rules and regulations (United Nations Survey, 2014).

Most of the adult learners $99(26.4 \%)$ and 45(12\%) use e-commerce services to access their passport services to a great and to a very great extent while $90(24 \%)$ use it to some extent and $69(18.4 \%)$ use it to a little extent. Most of the instructors 36(33.4\%) use e-consumer services to access their passports while $30(27.8 \%)$ do not use it all, $15(13.9 \%)$ use it to some extent and a great extent respectively and only $12(11.1 \%)$ indicated that the adult learners use it to a very great extent. The findings suggest that adult learners are using e-commerce to access online services such as past application processes. This implies that people are embracing new and modern technology very fast. There is also an increasing expectation from citizens for easier access to more public information and government services from anywhere, anytime through different channels. This makes the public sector to be under pressure to transform itself to respond to changes and radically explore new ways to meet demands (Walji, Deacon, Small \& Czerniewicz, 2016).

In regards to land ownership search, the majority of respondents $114(30.4 \%)$ and $42(11.2 \%)$ indicated that they use e-consumer services to a great and very great extent respectively. Contrary, only $81(21.6 \%)$ use it to some extent while $57(15.2 \%)$ use it to some and a little extent. However, $81(21.6 \%)$ indicated they do not use e-commerce to conduct land ownership searches. Contrary to these findings, most of the adult instructors $69(60.9 \%)$ search land ownership to a very little extent while $9(8.3 \%)$ search for land ownership to a little extent and $12(11.1 \%)$ use it to some and a great extent respectively but only $6(5.6 \%)$ indicate that the learners use it to a very great extent. These findings imply that individuals are conducting land searches to a moderate extent which may be associated with the lack of awareness of the presence and effectiveness of the e-consumer services.

Most of the adult learners111 (29.6\%) indicated that they use e-commerce services to a great extent and only $33(8.8 \%)$ use it to a very great extent to register their companies while $81(21.6 \%)$ do not use them to register the companies. However, $77(15.2 \%)$ and $81(21.6 \%)$ use it to a little and some extent respectively. Lastly, the table shows that most of the respondents $111(29.6 \%)$ use it to some extent while $93(24.8 \%)$ and $30(8 \%)$ use it to a great extent and a very great extent. Most of the instructors 33(30.6\%) and 24(22.2\%) indicated that their adult learners register companies using e-commerce to a very little extent and no extent at all respectively. only $15(13.9)$ and $9(8.3 \%)$ use the services to a great and a very great extent respectively. Generally, the findings show that there is an increase in embracing digital channels, including counter services, telephone service, web portal, e-mail, SMS, mobile portal, mobile app, social media, public kiosks, and intermediaries through public-private partnerships to promote access to information (Sebastian, 2011). These findings reveal that individuals are increasingly using different e-consumer platforms, but their use is not very extensive. 
Table 5. Use and Rating of E-commerce Services

\begin{tabular}{llllllllll}
\hline \multirow{2}{*}{ Use } & \multirow{2}{*}{$\mathrm{N}=375$} & \multicolumn{3}{c}{ Use } & \multicolumn{7}{c}{ Rate } \\
\cline { 2 - 9 } & & Yes & No & Excellent & Good & Average & Below Average & Poor & N/A \\
\hline Use of Digital & $\mathrm{F}$ & 135 & 240 & 72 & 96 & 102 & 54 & 36 & 15 \\
Gadgets & $\%$ & 36 & 64 & 19.2 & 25.6 & 27.2 & 14.4 & 9.6 & 4 \\
Online Shopping & $\mathrm{F}$ & 189 & 183 & 63 & 114 & 87 & 69 & 30 & 12 \\
& $\%$ & 50.4 & 49.6 & 16.8 & 30.4 & 23.2 & 18.4 & 8.0 & 3.2 \\
Paying for online & $\mathrm{F}$ & 168 & 207 & 69 & 87 & 105 & 72 & 33 & 9 \\
shopping & $\%$ & 44.8 & 55.2 & 18.4 & 23.2 & 28.0 & 19.2 & 8.8 & 2.4 \\
Cheaper Online & $\mathrm{F}$ & 210 & 165 & 75 & 123 & 99 & 39 & 27 & 12 \\
Transactions & $\%$ & 56 & 44 & 20 & 26.4 & 26.4 & 10.4 & 7.2 & 3.2 \\
\hline
\end{tabular}

Most of the respondents $189(50.4 \%)$ indicated that they use online shopping platforms while $186(49.6 \%)$ indicated that they do not use online shopping platforms. Most of the respondents $114(30.4 \%)$ and $63(16.8 \%)$ rated online shopping as good and excellent respectively while $87(23.2 \%)$ rated it as average, $69(18.4 \%)$ below average and $30(8.0 \%)$ rated it as poor. Consumer literacy includes aspects such as knowledge as understanding consumer rights and marketing practices, having the interpersonal skills to manage service encounters and make complaints, and asserting one's voice, and achieving agency in the marketplace. This broader idea of consumer competency does not dwell within the consumer alone but is socially enacted and evaluated. A social practice approach to literacy conceptualizes adults to be "acting concerning a situation, taking into account other people, social and cultural norms, their own experience, and, of course, the technical knowledge they need to encode or decode" text. The proliferation of various forms of literacy-computer literacy, health care literacy, financial literacy, and so on - points to the contextual factors implicated in the importance of the broad practice of consumer literacy.

The study also found that most of the respondents 207(55.2\%) did not pay for services online while $168(44.8 \%)$ pay services online. The majority of the respondent's further rated online payment services $105(28 \%)$ rated it as average, 72(19.2\%) as below average, 33(8.8\%) as poor while $69(18.4 \%)$ rated it as excellent, and $87(23.2 \%)$ as good. The majority of respondents $210(56 \%)$ indicated they use cheaper online transactions while $165(44 \%)$ do not use cheaper online transactions. The majority of respondents further rated cheaper online transactions as good $123(32.8 \%), 75(20 \%)$ as excellent, $99(26.4 \%)$ as average, $39(10.4 \%)$ below average, and $27(7.2 \%)$ as poor. Generally, most of the respondents indicated that they use digital gadgets, conduct online shopping, make payments, and do cheap online transactions. These are in line with the assertions by Walji, Deacon, Small, and Czerniewicz (2016). There is also an increasing expectation from citizens for easier access to more public information and government services from anywhere, anytime through different channels. This makes the public sector to be under pressure to transform itself to respond to changes and radically explore new ways to meet demands. 


\section{Conclusion}

This study aimed to determine the extent of the use of e-consumer services among adult learners in Nairobi County. The study found that most of the adult learners indicated that they use e-consumer platforms but in regards to the extent to which they use them, the study found that the use is mainly to some extent as the responses were highly dispersed with some cases revealing that some of the adult learners do not use e-commerce services at all. Generally, the study concludes that the use of e-consumer services among adult learners in Nairobi County is moderate.

It can, therefore, be argued that in general, adult learners use e-commerce services only to some extent. Their use of e-commerce services entails the use of digital gadgets, doing online shopping, paying for online shopping, and searching for cheap online products.

The study, therefore, recommends that the adult learners should be further educated and exposed to the different aspects of e-consumer services and be taught how to the different platforms to access the services online.

\section{References}

Cohen, S. A., Prayag, G., \& Moital, M. (2014). Consumer behavior in tourism: Concepts, influences, and opportunities. Current Issues in Tourism, 17(10), 872-909. https://doi.org/10.1080/13683500.2013.850064

Deloitte, (2013). The digital transformation of customer services: Our point of view. Deloitte Touche Tohmatsu Limited.

Gitari, S. M. (2020). Reforming the institutional and legal frameworks of E-commerce in Kenya; consumer rights protection in the digital economy (Doctoral dissertation, Strathmore University).

Islam, M. S., \& Eva, S. A. (2019). Electronic Commerce toward Digital Bangladesh: Business Expansion Model Based on Value Chain in the Network Economy. Studies in Business \& Economics, 14(1). https://doi.org/10.2478/sbe-2019-0007

Kabugumila, M. S., Lushakuzi, S., \& Mtui, J. E. (2016). E-commerce: an overview of adoption and its effective implementation. International Journal of Business and Social Science, 7(4), 243-252.

Kent, E. (2010). An investigation into factors affecting teachers uses of ICT in an Irish post primary school: a case approach (Master thesis). Department of Education and Professional Studies, University of Limerick.

Khan, A. G. (2016). Electronic commerce: A study on benefits and challenges in an emerging economy. Global Journal of Management and Business Research.

Khan, H. U., \& Uwemi, S. (2018). What are e-commerce possible challenges in developing countries: a case study of Nigeria. International Journal of Business and Systems 
Research, 12(4), 454-486. https://doi.org/10.1504/IJBSR.2018.095077

Kimathi, D. K., Mukulu, E., \& Odhiambo, R. (2019). Effect of Digital Marketing on the Performance of MSMES in Kenya. Journal of Marketing and Communication, 2(1), 1 23.

Maijo, S. N. (2020). Learners' Perception and Preference of Open and Distance Learning Mode at the Institute of Adult Education, Tanzania. East African Journal of Education and Social Sciences (EAJESS), 2(3), 79-86.

Makini, F. M., Mose, L. O., Kamau, G., Mulinge, W., Salasya, B., Akuku, B., \& Makelo, M. (2020). The Status of ICT Infrastructure, Innovative Environment and ICT4AG Services in Agriculture. Food and Nutrition in Kenya, 5(11), 75.

Mazlan, D., Redzuan, A. M., \& Bakar, D. A. (2014). Consumer education in creating a consumer conscious nation. Procedia-Social and Behavioral Sciences, 155, 448-453. https://doi.org/10.1016/j.sbspro.2014.10.320

Mbugua, P. N. (2009). Factors influencing the implementation of adult education curriculum in Nairobi West district. A project report, University of Nairobi.

Mensah, I. K. (2019). Predictors of Electronic Government Services Adoption: The African Students' Perspective in China. International Journal of Public Administration, 42(12), 997-1009. https://doi.org/10.1080/01900692.2019.1572621

Mohammed, S. (2013). Implementation of Integrated Functional Adult Education Program: the case of Obora Sub-Zone of Eastern Hararghe: MA thesis. Haramaya University. Ethiopia

Motschilnig, R. (2014). Wider Benefits of Adult Education-An Inventory of Existing Studies and Research. Retrieved from http://www.dvv-internation.de/index.php?article$\mathrm{id}=1321$ \& clang $=1$

Müller, F. A., \& Wulf, T. (2020). Technology-supported management education: a systematic review of antecedents of learning effectiveness. International Journal of Educational Technology in Higher Education, 17(1), 1-33. https://doi.org/10.1186/s41239-020-00226$\mathrm{x}$

Nantembelele, F. A., \& Gopal, S. (2018). Assessing the challenges to e-commerce adoption in Tanzania. Global Business and Organizational Excellence, 37(3), 43-50. https://doi.org/10.1002/joe.21851

Njoroge, J. (2021). The role of M-pesa in enabling E-commerce in Kenya.

OECD (2008). Beyond Rhetoric: Adult Learning Policies and Practices. Paris: OECD.

Omondi, B. (2020). External factors influencing consumer purchase decision by home furniture buyers: case of Victoria Courts Kenya (Doctoral dissertation, Strathmore University). 
Putera, A R., Mokhtar, M., \& Candra, M. (2014). A Case Study: The Local EducationAuthorities (LEAs) Capacity Support on ICT Integration National Policy in PublicSecondary Schools in Kepulauan Riau Province, Indonesia. Journal Curriculum and Teaching, 4(1). http://dx.doi.org/10.5430/jct.v4n1p14

Rasouli, K., Ahqr, G., \& Asadzadeh, H. (2020). The Effectiveness of Teaching Learning Strategies on the Professional Competence of Adult Education Educators of the Literacy Movement Organization. Curriculum Research, 1(2), 89-96.

Seidel, S., \& Blanquart, C. (2020). E-commerce in France and Germany a comparative analysis. Recherche Transports Sécurité.

UNESCO (2013). Adult and youth literacy. September 2013, No.26

UNESCO (2013). Adult and youth literacy. September 2013, No.26

United Nations (2010). UN E-Government Survey (2010).

Wagunya, J. (2018). Influence of Information Communication Technology Adoption on Service Delivery in County Governments in Kenya, A Case of Murang'A County Government (Doctoral dissertation, University of Nairobi).

Wairiuko, J. W., Nyonje, R., \& Omulo, E. O. (2018). ICT infrastructure and adoption of Egovernment for improved service delivery in Kajiado country, Kenya. European Journal of Business and Management, 10(30), 205-21. https://doi.org/10.30845/ijbss.v9n10p10

Walji, S., Deacon, A., Small, J., \& Czerniewicz, L. (2016). Learning through engagement: MOOCs as anemergent form of provision. Distance Education, 37(2), 208-223. https://doi.org/10.1080/01587919.2016.118440

Xu, Z., Banerjee, M., Ramirez, G., Zhu, G., \& Wijekumar, K. (2019). The effectiveness of educational technology applications on adult English language learners' writing quality: meta-analysis. Computer Assisted Language Learning, 32(1-2), 132-162. https://doi.org/10.1080/09588221.2018.1501069

Yin, R. K. (2015). Qualitative research from start to finish. Guilford publications.

\section{Copyright Disclaimer}

Copyright for this article is retained by the author(s), with first publication rights granted to the journal.

This is an open-access article distributed under the terms and conditions of the Creative Commons Attribution license (http://creativecommons.org/licenses/by/3.0/). 